\title{
The Ethiopian Orthodox Community in Jerusalem: New Archives and Perspectives on Daily Life and Social Networks, 1840-1940
}

\author{
Stéphane Ancel
}

According to Ethiopian accounts, a plague in 1838 killed every Ethiopian monk in Jerusalem. Dayr al-Sultan, the monastery on the roof of the Chapel of St. Helena, where Ethiopian and Coptic monks had lived together, was from then on occupied only by the Copts, with permission from the Armenian Patriarchate, the traditional protector of both Ethiopians and Egyptians in Jerusalem. Three years later, a new group of Ethiopian monks arrived in town and immediately accused the Copts of unfairly appropriating the site. This event marked the beginning of a long-term conflict in which Ethiopians fought with Copts and Armenians over ownership of Dayr al-Sultan. Indeed, between 1840 and 1940, Dayr al-Sultan was the site of disturbances, demonstrations, and fights. However, in addition to conflict, this period also witnessed the development of the Ethiopian Orthodox community in Jerusalem. From the second half of the nineteenth century, Ethiopians could acquire houses and lands in Jerusalem, their population grew and finally, in 1905, the Ottoman authorities designated a part of the town as Haret al-Habash, known today as the Ethiopian compound. Despite numerous obstacles, the small Ethiopian community thus managed to leave an indelible mark on Jerusalem.

The history of the Ethiopian community in Jerusalem during the nineteenth and twentieth centuries has attracted but a few scholars, mainly specialized in Ethiopian studies, and the majority of research has focused on the controversial ownership of Dayr al-Sultan. In collecting and analyzing documents on the Ethiopian presence, scholars have contributed, either consciously or unconsciously, to the Dayr al-Sultan debate. Among them are Enrico Cerulli, ${ }^{1}$ Otto Meinardus, ${ }^{2}$ and Archbishop Philippos. ${ }^{3}$ Our knowledge of the nineteenth- and

1 Enrico Cerulli, Etiopi in Palestina, 2 vols. (Rome: Libreria dello Stato, 1943-47).

2 Otto Meinardus, "The Ethiopians in Jerusalem," Zeitschrift für Kirchengeschichte 76, nos. 1/2 (1965), 3/4 (1965).

3 Abba Philippos, Know Jerusalem (Addis Ababa: Berhannena Selam Haile Selassie I Printing Press, 1972); Abba Philippos, The Rights of the Abyssinian Orthodox Church in the Holy

(C) STÉPHANE ANCEL, 2018 | DOI:10.1163/9789004375741_006

This is an open access chapter distributed under the terms of the prevailing CC-BY-NC-ND License at the time of publication. 
twentieth-century situation of Ethiopians owes much to Kirsten Pedersen and her pivotal work in $1983,{ }^{4}$ the first study devoted more to the development of the community as a whole than to Dayr al-Sultan. The principal aim of her study was to create a chronology of events related to the Ethiopian community in Jerusalem without a focus on the political, economic, or social context of the city. It appears, based on a small number of Ethiopian texts and European sources (travelers' narratives and British consular archives), that all previous studies neglected Ottoman and Arabic sources. In a similar way, a large part of French and Italian consular archives remained unstudied despite the later valuable works of Henrich Scholler and Alain Rouaud. ${ }^{5}$ More recent studies focus on the current situation of the community starting from the end of World War II. ${ }^{6}$

The Ethiopian Orthodox community appeared in early studies as a community unconnected to Jerusalem, with no role in local daily life. This probably explains why the Ethiopian community seldom appears in historical works about Jerusalem. Still today, the presence of Orthodox Ethiopians in Jerusalem is often considered as an exotic phenomenon; far removed from local historical processes.

The relatively overlooked story of Jerusalem's Ethiopians assuredly warrants new historical research. My research on the subject has been driven by a simple idea: the Ethiopian Orthodox community archives of 1840-1940 most certainly contain information about community members' interaction

Places: Documentary Authorities (Addis Ababa: Documentary Authorities, 1962). In 1959, the Ethiopian government, under the supervision of Philippos, published documents and their translation into Amharic through a publication called Zena Ityopya bä-Hagär Qeddest Iyärusalem [Story of Ethiopia in Holy Jerusalem]. Correspondence Respecting Abyssinians at Jerusalem, 1850-1867 (Addis Ababa, 1959).

4 Kirsten Pedersen, The History of the Ethiopian Community in the Holy Land from the Time of Emperor Tewodros II till 1974 (Jerusalem: Ecumenical Institute for Theological Research, 1983). See also Kirsten Pedersen, "The Historiography of the Ethiopian Monastery in Jerusalem," in Ethiopian Studies: Proceedings of the Sixth International Conference of Ethiopian Studies, ed. Gideon Goldenberg and Baruch Podolsky (Rotterdam: Balkema, 1986).

5 Heinrich Scholler, "The Ethiopian Community in Jerusalem from $185^{\circ}$ to the Conference of Dar-el-Sultan 1902, the political struggle for independence," in Ethiopian Studies, Proceedings of the Sixth International Conference of Ethiopian Studies, ed. Gideon Goldenberg and Baruch Podolsky (Rotterdam: Balkema, 1986); Alain Rouaud, "La protection française des Abyssins de Jérusalem (1843-1898). Aperçu," Transversalités 85 (2003).

6 See Steven Kaplan, "The Transnationalism of the Ethiopian Orthodox Tewahedo Church in the Holy Land," Journal of Levantine Studies 3, no. 1 (2013); Makonnen Zäwde, Ityopya enna Eyärusalem (Addis Ababa, 1991; Ethiopian calendar: 1998-99). 
with the surrounding population and institutions. Archival documents thus should not only be read as a series of events and dates, as they have been until now, but also as vectors of discourse, claims, and ideas of the people who produced them. Additionally, new archival material, previously neglected, must be collected.

This challenging research would be difficult for a scholar without the multidimensional support of the Open Jerusalem project (OJP) which has made it possible to gather sources produced in different religious, sociological, and institutional contexts in Jerusalem and elsewhere. Until now, OJP researchers and I have visited archives in Jerusalem, Addis Ababa, Istanbul, La Courneuve, Nantes, Rome and St. Petersburg, and the analysis of hundreds of documents is still in progress. ${ }^{7}$ The objective of this chapter is therefore not to present final results, but rather to present our methodological approach and suggest some research perspectives.

\section{Opening and Reopening Archives}

To my knowledge, until our project, Pedersen was the only scholar to have accessed the archives of the Ethiopian bishopric in Jerusalem. However, she was not able to examine and study the entire set of records, and the archives remained inaccessible to scholars up until recently. ${ }^{8}$ Thanks to the authorization of His Holiness Matthias, Patriarch of the Ethiopian Orthodox Church, and of His Grace Enbakom, ${ }^{9}$ Ethiopian Orthodox Archbishop of Jerusalem, I obtained access to unpublished material from the Ethiopian Archbishopric archives in Jerusalem. These records are preserved in the building of the Ethiopian bishopric in the old city on Ethiopian Monastery Street and are divided into two sections: the current administrative archives and the manuscript section.

The current administrative archival office preserves a heterogeneous set of documents dating from the end of the nineteenth century to the present. These

7 I would like to express my gratitude to my colleagues from the Open Jerusalem project for helping me during my research and sharing with me their knowledge concerning sources: Vincent Lemire, Yasemin Avcı, Falestin Naïli and Abdul-Hameed al-Kayyali, Maria Chiara Rioli, Angelos Dalachanis, Yann Potin and Leyla Dakhli.

8 Pedersen, History of the Ethiopian Community, 41, n. 90.

9 The transliteration system used in this chapter is an adaptation of the Aethiopica Encyclopedia one, simplified for easy reading. The names are also transliterated according to this system, except when it exists in another form in an official publication (for example, here Matthias and Enbakom for the Ethiopic Matyas and Enbaqom). 
do not constitute historical archives strictly speaking. Among the folders, seven contain documents produced during the period under scrutiny: Folders 6, 154, $356,358,359,360$ and a final folder with the Amharic title "yä-leyu leyu guday däräseññoč käzih yegäññalu" (receipts concerning diverse issues found here) contains different types of unclassified documents. The documents of the "administrative" archives, which comprise approximately $15^{\circ}$ pieces, date from the end of the nineteenth to the middle of the twentieth centuries. They are administrative and financial documents such as payment receipts, tickets, bank checks and documents, short letters, and notes. These documents are written in Arabic, English, French, German, Greek, and Armenian. Amharic marginalia are often added to documents in order to provide context. In addition to these folders, a report on Dayr al-Sultan written in 1925 by the lawyer Boris Nolde is classified as Folder $216 .{ }^{10}$ Also, a 122-page manuscript written in Amharic between 1903 and 1906 by an Ethiopian monk called Wäldä Mädhen was inventoried as Folder $172 .{ }^{11}$ Numerous precious parchment and paper manuscripts are carefully stored in a different room of the same building, the so-called "manuscript section." To date, no previously unknown document has been found. ${ }^{12}$ The Amharic text entitled "History of Dayr al-Sultan" [yä-Der Sultan tarik], written during the 1920 and still unpublished, is preserved in the Jerusalem archives as a large paper manuscript (code Ms. JE692E). ${ }^{13}$

I also launched an investigation in Ethiopia to discover archives about the Ethiopian Orthodox community in Jerusalem. The National Archives in Addis Ababa have recently received and inventoried the records of the Jerusalem Memorial of Ethiopian Believers association. Since its creation in 1963, this association has organized Ethiopian pilgrimages to the Holy Land. Inventoried in 2013 under the archival code 6.1, these archives comprise seven boxes (from 6.1.1 to 6.1.7), some containing more than ten folders, making a total of 71 folders. Documents preserved inside are mainly dated from the 1960 to the $1990 \mathrm{~s}$

$10 \quad$ In French and entitled "Consultation concernant les droits de la communauté religieuse abyssine en Palestine," it was translated into Amharic and English in Zena Ityopya, 45-50 (Amharic), 38-46 (English). See also Pedersen, History of the Ethiopian Community, 75.

11 Pedersen, History of the Ethiopian Community, 13, n. 35; see also Pedersen, "Historiography of the Ethiopian Monastery," 419-26.

12 The manuscript collection was shortly inventoried by Ephraim Isaac during the 1980s; See Ephraim Isaac, "Shelf List of Ethiopian Manuscripts in the Ethiopian Patriarchate of Jerusalem," Rassegna di Studi Etiopici 30-31 (1984).

13 About this text, see Pedersen, "Historiography of the Ethiopian Monastery," 419-26; Getatchew Haile, "Empress Tayitu and the Ethiopian Property in Jerusalem," Paideuma 35 (1989). 
and deal with the association's administrative life. However, the association also held some unpublished documents from the Ethiopian community in Jerusalem during the 1920 s.

Several events relating to the Ethiopian community during the second half of the nineteenth and the beginning of the twentieth centuries are documented in the British, French and Italian consular archives. The correspondence of the British consuls in Jerusalem, James Finn and Noel Temple Moore, provides information for the period from 1850 to 1868 and has been quoted regularly in previous studies. On the contrary, the French and Italian archives have not been studied exhaustively.

The French consular archives span from 1846 to 1913, years during which the French administration claimed to protect unofficially the Ethiopian community. A large volume of documents concerning Ethiopians is still preserved in Nantes and La Courneuve. Approximately 700 folios make up these archives. The Nantes archives (CADN) contain the records of the French consulate in Jerusalem (code $294 \mathrm{PO}$ ). Two boxes contain documents about the Ethiopian community in Jerusalem: 294/PO/A/134 (1846-1912, 322 folios) and 294/PO/A/135 (1881-1913, 155 folios). The French Ministry of Foreign Affairs in La Courneuve holds a large folder containing documents about the Ethiopian community in Jerusalem (1898-1907, 325 folios). These documents are part of a file entitled "correspondances politiques et commerciales, nouvelle série-cPc" and are contained in the subfile dedicated to the Vatican ("Saint-Siège/89").

The Italian consulate in Jerusalem also claimed to protect Ethiopians during the same period until the official recognition of this protection in 1902. At the Italian Ministry of Foreign Office archives (Archivio storico degli affari esteri, ASD), the subfile dedicated to Ministry of Italian Africa (Ministero dell'Africa Italiana) preserves five boxes totally dedicated to the Ethiopian community in Jerusalem, containing more than 200 folios each: boxes $42^{-1}$ (1885-90), 42-2 (1897-1902), 42-3 (1902-3), 42-4 (1904-5) and 42-5 (1906-12).

The OJP is currently carrying out a colossal collection of documents in the Ottoman State Archives (Başbakanlı Osmanlı Arşivi, BOA) in Istanbul. Among the files dealing with the Ottoman administration of Jerusalem (petitions, justice, public works) dated from 1840 to 1917 , one also finds many documents from the Orthodox Ethiopian community. More than 185 files (more than 600 documents) have been discovered and are currently under analysis. These documents include letters, reports and decrees produced by Ottoman officials as well as letters written by Ethiopian authorities.

Other documents located at other archives will be also collected. Letters from the Ethiopian community to Antonin Kapustin at the archives of the Russian Academy of Sciences in St. Petersburg (fond 214) will be collected and 
analyzed. Finally, Georges Hintlian of the Gulbenkian Library has sent me the translation of the $1875^{-76}$ diary of the dragoman of the Armenian Patriarchate, which is preserved in the Archives of the Armenian patriarchate of Jerusalem.

\section{Is Ethiopian Isolation in Jerusalem Overestimated?}

Previous studies on the Ethiopian community in Jerusalem refer to two types of institutions that played a role in the development of the Ethiopian Orthodox community: the Ethiopian monarchy and the Western consular authorities. Other institutions or authorities in Jerusalem, such as Coptic, Armenian or Ottoman entities, though appearing rarely, are invariably represented in a very negative way.Jerusalem is depicted as a dangerous land in which Ethiopians are surrounded by various enemy groups and only their motherland, or European countries, could assist them. The Ethiopian community is presented as lonely and lacking local connections.

Enrico Cerulli, Otto Meinardus and Kirsten Pedersen have used British sources to explore the condition of Ethiopians in Jerusalem during the nineteenth century. ${ }^{14}$ According to these sources, Ethiopians were completely isolated. James Finn, the British consul in the city, wrote on August 17, 1852, that

I shall very willingly attend to those instructions in favour of the poor and oppressed [Ethiopian] people, but I fear it will often require delicate management in using those friendly offices, since they have powerful enemies in the rich Armenian community and the vindictive Copts, and are themselves of very hot temperament. ${ }^{15}$

Such statements must have discouraged scholars from examining the relationship of the Ethiopians with local institutions. Western consular authorities are an exception to this, however. For example, to study the end of the nineteenth and the beginning of the twentieth centuries, Pedersen focused on Russian and Italian endeavors to protect Ethiopians and to help Ethiopian monarchs to

14 Cerulli, Etiopi, vol. 2, 274-327; Meinardus, "The Ethiopians," 131-37; Pedersen, History of the Ethiopian Community, 17-29.

15 British consul to the Earl of Malmesbury (August 17, 1852), Jerusalem. Quoted by Cerulli, Etiopi, vol. 2, 290; Meinardus, "The Ethiopians," 133; Pedersen, History of the Ethiopian Community, 21. 
improve their position in the town. ${ }^{16}$ Following her work, other studies of the Ethiopian community in Jerusalem focused on the characteristics of French and Italian protection ${ }^{17}$ and contributed, probably unconsciously, to the presentation of Ethiopians as alienated from local social networks.

Another factor that played a role in overestimating the isolation of Ethiopians is related to the texts produced by the official Ethiopian historiography, chiefly made up of two texts: the "History of Dayr al-Sultan," composed of several different documents among which are copies of the emperor's letters ${ }^{18}$ and a history of Empress Taytu Betul (ca. 1853-1918) composed after $1930 .{ }^{19}$ Both texts depict the Ethiopian community during the nineteenth century as an isolated entity, surrounded by enemies and finally saved by the devotion and ability of Emperor Menilek II (r. 1889-1913), his wife, Taytu Betul, and his granddaughter Empress Zäwditu (r. 1916-30).

Nonetheless, it would be useful to carefully analyze the context and the aim behind the production of these sources before drawing any conclusions. Ethiopian monarchs used official texts as panegyrics and therefore such texts should be evaluated carefully. These texts aimed at explaining why the Ethiopian community encountered great difficulties during the nineteenth century and tried to justify the late involvement of monarchs and the aristocracy in an attempt to conserve the reputation of the Ethiopian monarchy and aristocratic ideology.

Concerning the British sources, one should interrogate the political and religious objectives of James Finn. ${ }^{20}$ In favor of British involvement in Ethiopian affairs in Jerusalem, Finn supported British actions that exaggerated the isolation of the Ethiopians. It is crucial to meticulously examine the European perception and discourse on Ethiopia and Jerusalem's Ethiopians with regards to European discourse on Jerusalem and Africa more generally at that time. The partial analysis of a few European sources, and their connection to some Ethiopian ones, persuaded scholars that between $185^{\circ}$ and 1920 , Ethiopians were isolated and placed themselves under the protection of the European consulates that, in turn, helped Ethiopian monarchs.

16 Pedersen, History of the Ethiopian Community, 49-52, 62-77.

17 Scholler, "The Ethiopian Community," 487-500; Rouaud, "La protection française," 63-74.

18 Ethiopian Archbishop Residence in Jerusalem (EARJ), Manuscript section, MS JE692E. About this text, see Pedersen, "Historiography of the Ethiopian Monastery," 421.

19 About this text, see Getatchew Haile, "Empress Tayitu," 67-81.

20 Concerning James Finn and British policy in Jerusalem, see Mordechai Eliav, Britain and the Holy Land, 1838-1914: Selected Documents from British Consulate in Jerusalem (Jerusalem: Yad Izhak Ben-Zvi, 1997); Falestin Naili, "La mémoire et l'oubli à Artas: un élément de l'histoire rurale de la Palestine, $1848-1948$ " (PhD diss., University of ProvenceAix-Marseille I, 2007), 65-79. 


\section{Behind the "Veil" of the European Sources}

In a letter dated to 1898, the French consul Auzépy justified the French involvement in an 1893 conflict between Copts and Ethiopians:

It was difficult for me not to take into consideration these complaints [of Ethiopians] and, like my [Russian] colleague M. Yacolew, I did not miss the chance, in the name of humanity and of public hygiene, to intercede informally on behalf of Tewfick Bey [Turkish governor].21

The arguments of Auzépy are similar to these of Finn from 1852; compassion seems to have guided European intervention in favor of Ethiopians, who were "poor and oppressed people," according to Finn. ${ }^{22}$ Commentators and historians contributed to the spreading of this idea, ${ }^{23}$ sometimes forgetting that European governments saw many advantages in supporting Ethiopians in Jerusalem. European countries' influence in the Horn of Africa and the consequent competition among them became an issue from the mid-nineteenth century onwards. By protecting Ethiopians in Jerusalem, Europeans must have expected a gesture of goodwill from the Ethiopian government that would improve their position and reputation there. ${ }^{24}$ In Jerusalem, the protection of the Ethiopian community could be seen as a strategy for preventing other countries or communities from enlarging their sphere of influence too. ${ }^{25}$

European sources have created a "veil" that not only prevents a thorough examination of the relationships between Ethiopians and local institutions, but also hides Ethiopian involvement in the Jerusalemite social networks. Even if the documents describe facts and sometimes events related to the Ethiopian community, we need to keep in mind that they are produced by Europeans and thus they represent their point of view. Such documents describe, explain and justify British, French and Italian consular policies to the metropolitan authorities. They emphasize the role of the European consular administrations while they downplay the role of other institutions, which

21 Nantes Diplomatic Archives Centre (CADN), French consul in Jerusalem to French Ministry of Foreign Affairs (July 1, 1898), Jerusalem, 294/PO/A/135, fol. 39 .

22 See note 15.

23 Meinardus, "The Ethiopians," 131.

24 CADN, French consul in Cairo to French consul in Jerusalem (January 25, 1882), Cairo, 294/PO/A/134, fol. 53-56.

25 CADN, French consul in Jerusalem to French Ministry of Foreign Affairs (December 15, 1880), Jerusalem, 294PO/A/134, fols. 21-25. 
are depicted as unfair, authoritarian and useless. The isolation and poverty of Ethiopians in Jerusalem was a topos serving as a pretext for their intervention. The discourse of some Europeans concerning Jerusalem ${ }^{26}$ is reminiscent of other discourse on African countries at the same time. Africa was portrayed as a continent of empty lands, devoid of effective governments, whose inhabitants were poor and isolated from the rich, prosperous and civilized Europe. ${ }^{27}$ One may wonder whether Ethiopians in Jerusalem did not hold the concurrent disadvantages, in European eyes, of both being Africans and living in Jerusalem.

The fact that these documents probably overemphasize the role of the European consular authorities in Ethiopian affairs does not mean that they do not contain information about the daily lives of Jerusalem Ethiopians. Careful analysis and cross-checking with other sources shows that Ethiopians in Jerusalem organized their life mostly away from European influence. The same documents illustrate that Ethiopians always solicited European help after they had negotiated first with local authorities and local communities, not before. For example, in 1850, Ethiopians met the British consul, Finn, in order to seek his help with Dayr al-Sultan, a problem that had arisen several years before. The Islamic court of Jerusalem had already issued three decisions on the matter, in 1845,1846 and $1848 .{ }^{28}$ When problems in Dayr al-Sultan between Ethiopians and Copts reappeared in 1862-63, 1880-83, 1890-93 and in 1898, Ethiopians systematically solicited European support (Russian, French or Italian) but only after the breaking off of negotiations with the local authorities. For example, on October 21, 1890, Ethiopians asked for help from the French consul because the negotiations with local authorities had stalled. ${ }^{29}$ Each consul considered that his own action was the only solution for the Ethiopians. The Ethiopians, though, had several other options, and sometimes solicited help from the British, Russian, French and Italian consulates for the very same problem. On

26 Vincent Lemire, Jérusalem 19oo: La ville sainte à l'âge des possibles (Paris: Armand Colin, 2013), 105-8.

27 William B. Cohen, Français et Africains. Les Noirs dans le regard des Blancs, 1530-1880 (Paris: Gallimard, 1981).

28 Documents of the Islamic court decisions were copied by Italians in 1905 and preserved. See Historical Archive of the Italian Foreign Ministry (ASD), Ministero dell'Africa Italiana, posizione $42-4$.

29 CADN, French consul in Jerusalem to French Ministry of Foreign Affairs, October 21, 1890, Jerusalem, $294 \mathrm{PO} / \mathrm{A} / 135$, fol. 31 . 
April 15, 1891, the Italian consul said that he had contributed to the liberation of an Ethiopian who had been arrested during the 1890 confrontation. ${ }^{30}$

These European documents also remind us that Ethiopians were strongly linked to the Armenian and Greek Orthodox patriarchates in Jerusalem whose members were mostly local Ottoman subjects. The Armenian authorities were considered to be the protectors of Ethiopians and Copts, while at the same time some Ethiopians were accommodated in Jerusalem by the Greek Orthodox patriarchate. It seems that Ethiopians were involved in a local network even before Ethiopian contact with European entities. The problem was that from the 1850 s onwards, such a local network did not satisfy the Ethiopian expectations concerning Dayr al-Sultan. European support was seen as a complement to the intercession of Armenian and Greek efforts in the attempts to make headway on the Dayr al-Sultan conflict. But the appeal to European support did not mean that Europeans replaced local authorities as the main interlocutors of Ethiopians in Jerusalem. The Ethiopian government could still enter into contact with Istanbul in order to defend its community. For example, in 1882, Ethiopian Emperor Yohannes IV (1872-89) officially complained about the behavior of the Coptic Bishop Baselios in Jerusalem (fig. 3.1). ${ }^{31}$

An important constraint prevented the replacement of a "local" Ethiopian network by a "European" one. Until 1902, the Ottoman state regularly refused foreign protection to Ethiopians. In the eyes of the Ottoman state, Ethiopians were local people and not foreigners and thus the state protested against all attempts to present Ethiopians as citizens of a foreign country. In 1862, the Ottomans rejected the idea of British protection of Ethiopians. ${ }^{32}$ In 1881, they complained against French policy and expressed themselves in favor of Ethiopians while in 1882, they rejected Russian and Greek protection. ${ }^{33}$ In 1893 , the Ottoman authorities in Istanbul expressed concern about the increasing number of Ethiopians in Jerusalem bearing Italian passports (fig. 3.2). ${ }^{34}$ When in 1902, the Sublime Porte finally accepted the Italian protection of Ethiopians,

30 ASD, Ministero dell'Africa Italiana, Italian consul in Jerusalem to Italian Ministry of Foreign Affairs, April 15, 1891, Jerusalem, posizione 42-1.

32 Consul Finn to Sir H. Bulwer (March 11, 1862), Jerusalem. Quoted by Cerulli, Etiopi, vol. 2, 312-13.

CADN, French consul in Istanbul to French consul in Jerusalem (December 9, 1881), Istanbul, 294/PO/A/135, fol. 25; CADN, French consul in Jerusalem to French Ministry of Foreign Affairs (September 6, 1882), Jerusalem, 294/PO/A/134, fols. 48-49. BOA, Hariciye Nezareti fon (Ministry of Foreign Affairs fond), HR.HMS.ISO.179.19. 


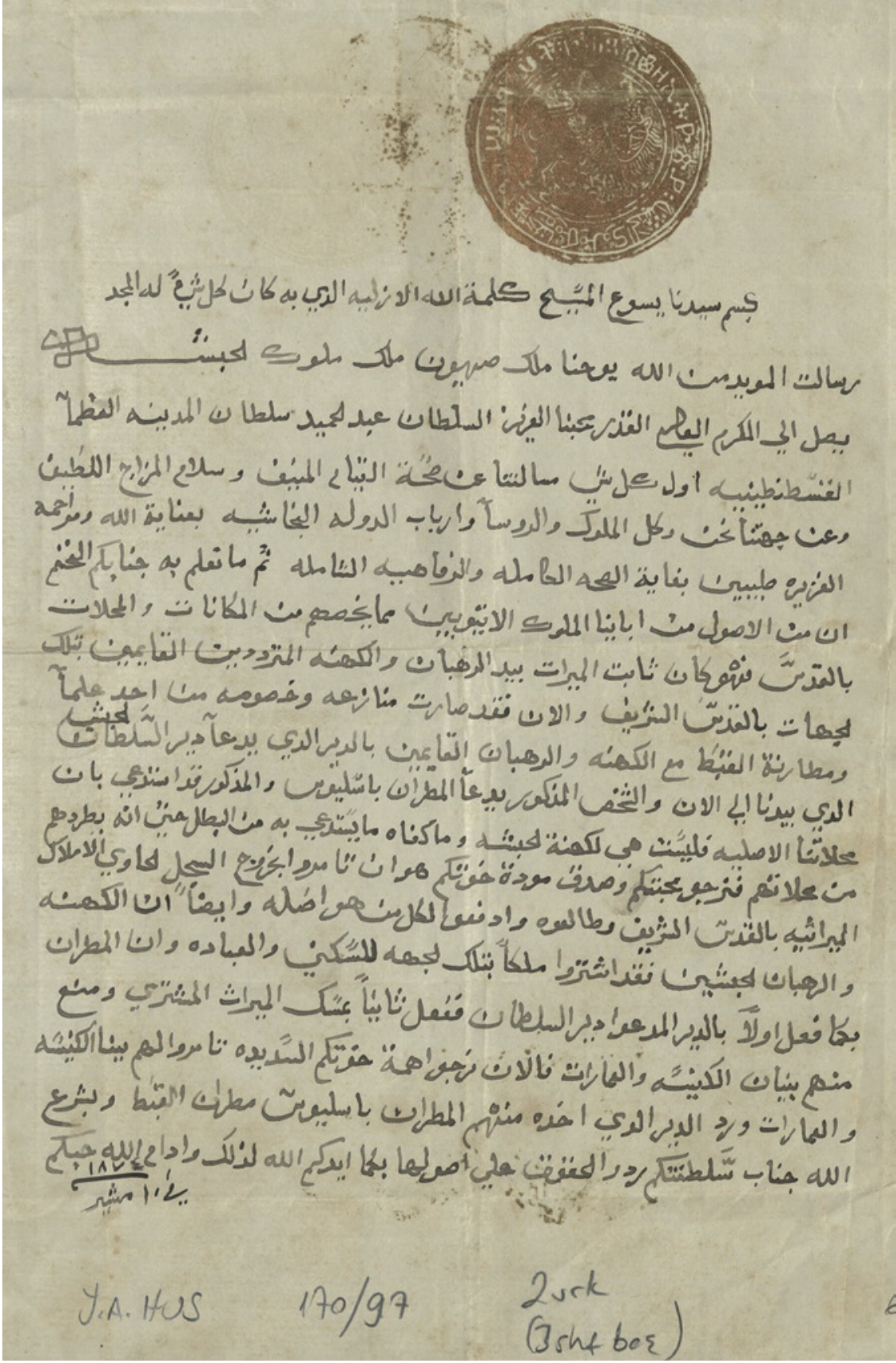

FIGURE 3.1 Letter of Emperor Yohannes IV to the sultan, dated Yäkkatit 24, 1874 (Ethiopian Calendar)/March 2, 1882.

BOA, YILDIZ FON, Y.A.HUS.170-97. 


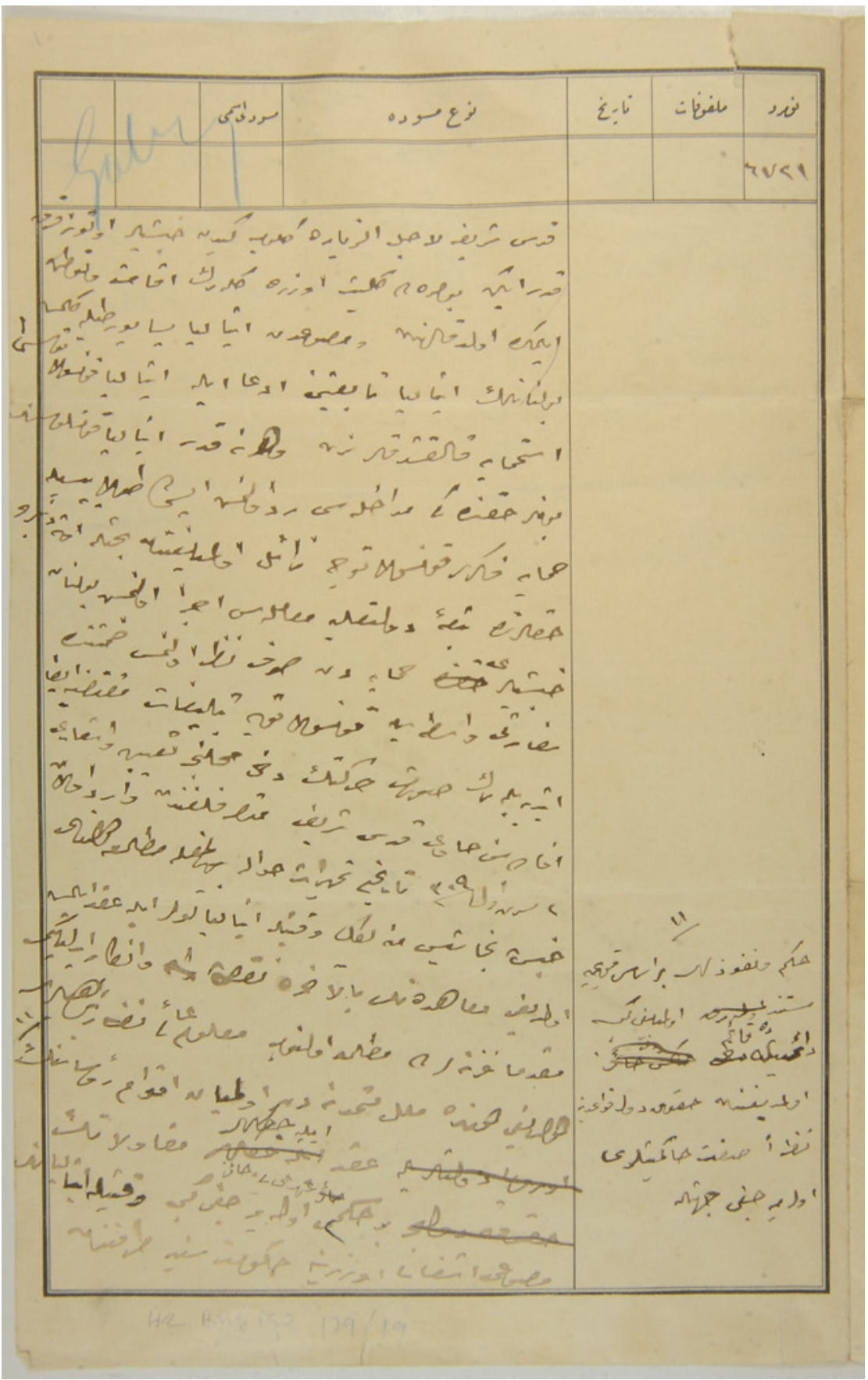

FIGURE 3.2 Ottoman report concerning the increasing number of Ethiopians in Jerusalem bearing Italian passports, 1893 .

BOA, HARICIYE NEZARETI FON, HR.HMS.IŞO.179.19. 
it imposed important constraints and specified that Ethiopians were to stay under Ottoman jurisdiction. ${ }^{35}$

\section{Behind the "Veil" of the Ethiopian Sources}

Documents produced by Ethiopians and preserved in Ethiopian or European archives are much more scarce, but should also be analyzed carefully. These documents proposed a discourse that tends to hide the complex Ethiopian network operating in Jerusalem. A letter dated December 6, 1880 arrived at the French consulate in Jerusalem signed by the Ethiopian community assembly. The letter began:

Monsieur le Consul, we members of the Abyssinian community in the Holy Lands, have the honor to say to you that we are poor pilgrims who remain at home in the Convent of the Sultan, in the accommodation of indigent Abyssians. ${ }^{36}$

Thanks to such Ethiopian letters received by Europeans, it is possible to detect an extremely stereotyped Ethiopian discourse regarding their own situation in Jerusalem. These texts emphasize the poverty and isolation of the community, denounce oppression and systematically depict the European consul as the community's last resort. Without denying the difficulties the Ethiopian community faced at the time, the historian should nevertheless question the elements of this discourse.

Documents concerning an Ethiopian monk called Abd Mariam (Gäbrä Maryam for Ethiopians) illustrate the problem posed by Ethiopian sources. Abd Mariam was an Ethiopian monk living in Dayr al-Sultan during the second half of the nineteenth century. His name was associated with different cases involving the Ethiopian community and reported in documents preserved in French, Russian and Armenian archives. In 1875, Abd Mariam signed two letters addressed to Antonin Kapustin, archimandrite in the Russian Ecclesiastical Mission in Jerusalem. In these two letters, the Ethiopian monk requested Russian protection and intervention for the Ethiopian community.

35 CADN, Translation of the Irade dated AH 1320, concerning Italian protection over the Ethiopians, 294/PO/134, fols. 271.

36 CADN, Ethiopian letter translated into French (December 6, 1880), Jerusalem, $294 \mathrm{PO} / \mathrm{A} / 134$, fol. 19 . 


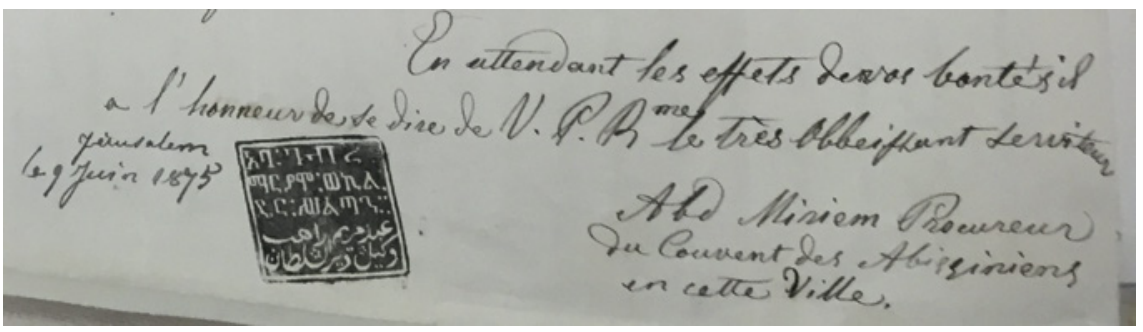

FIGURE 3.3 Letter from Abd Mariam to Antonin Kapustin, archimandrite in the Russian Ecclesiastical Mission in Jerusalem, December 6, 1875, Jerusalem.

ST. PETERSBURG DEPARTMENT OF THE ARCHIVE OF THE ACADEMY OF SCIENCES (SPBFARAN), FOND 214.

The first one, dated June $9,1875,{ }^{37}$ contains an explanation by Abd Mariam that Ethiopian monks, led by the Coptic Bishop Baselios, had complained about him because, in their eyes, he did not give them a part of the money sent by Ethiopian Emperor Yohannes IV. A trial was therefore organized, and Abd Mariam asked for Russian support. At the end of the letter, he signed himself as "Abd Miriam, procurator of Ethiopian convent in this town" and added his seal (fig. 3.3).

During the second half of the nineteenth century, the Ethiopian community regularly received money from Ethiopia. ${ }^{38}$ In 1867 , the Armenian patriarchate informed the French consul in Jerusalem that Abd Mariam had to go to Saïda (Sidon) in order to receive money from Ethiopia. This money was entrusted to the French administration and was supposed to help the community in Jerusalem. ${ }^{39}$ Of course, we cannot say for certain that the money received in 1867 created a problem in 1875 . But it is interesting to observe that in 1867 Abd Mariam was in charge of receiving money from Ethiopia.

In June 1875, Abd Mariam describes the situation in an ambiguous way. Did the Coptic bishop complain about him directly, or in a more general fashion, about members of the community? The reader does not know. Abd Mariam signed the letter with his seal as procurator of the community, thus presenting

37 St. Petersburg Department of the Archive of the Academy of Sciences (spbFaran), Abd Mariam to the archimandrite of Russian Mission (December 6, 1875), Jerusalem, fond 214.

38 Bairu Tafla, A Chronicle of Emperor Yohannes IV (1872-1889) (Wiesbaden: Harrassowitz, 1977), 162-89; See also Pedersen, History of the Ethiopian Community, 45.

39 CADN, French consul in Jerusalem to French vice-consul in Saïda (March 9, 1867), Jerusalem, 294PO/A/134, fol. 9 . 
himself as the representative of Ethiopians. Did this case represent a new step in the conflict between Ethiopians and Copts?

A few months after the first letter to Kapustin, the situation became more complicated. Abd Mariam sent a second letter to Kapustin dated November 12, $1875{ }^{40}$ In that letter, he complained about the Armenian authorities' lack of resource provision. Because of previous problems between Ethiopians and Armenians not specified in the letter, the latter decided to give food only to a few Ethiopian monks in Dayr al-Sultan. Abd Mariam presented himself as the representative of Ethiopian members who were deprived of provisions, asking the Russian Mission for help. Like the first one, this second letter is also very ambiguous. Abd Mariam depicted himself again as the representative of the whole Ethiopian community, but he wrote that some Ethiopians did continue to receive food from the Armenians. Had a new conflict between the Armenians and Ethiopians arisen or not?

An Armenian source confirms the delicate situation inside the Ethiopian community. The Armenian patriarchate dragoman's diary from $1875^{-76}$ provides valuable information. The author describes a major problem with regards to the food supply to Ethiopians. One day, an Ethiopian called Mika'el requested the food that the Armenians traditionally provided to the Ethiopians. The Armenian patriarch agreed to this and the day after, the provisions were ready to be collected by the Ethiopians. However, nobody came. As a result, the Armenians decided to send the supplies to the Ethiopians. Ethiopian monks led by Abd Mariam forbade the food from entering Dayr al-Sultan. Someone from the Armenian patriarchate called the local authorities. Police arrived and finally the food found its way to the monastery. Some days later, an Ethiopian representative went to the dragoman's office and explained that the community was ready to petition against Abd Mariam.

The Armenian source refers most probably to the problem that was reported by Abd Mariam in his letters to Kapustin. It shows that the Ethiopian community was divided and Abd Mariam represented only a part of it, for he was accused by the other part. This case highlights the need for careful analysis and cross-checking of sources: because an Ethiopian presented himself as a representative of the Ethiopian community does not mean that the entire community was involved in his demand. Likewise, just because these documents highlighted the community's poverty and isolation does not mean this was always the case. Documents produced by Ethiopians proposed an oriented 
view which often hid the great complexity of the facts. The same is true of European documents.

Cases involving the name of Abd Mariam do not end here. In 1880, the French consul received a letter signed by the "assembly of Ethiopian community" complaining about the Armenian authorities. ${ }^{41}$ I quote the letter's introduction at the beginning of this section. The letter states that Abd Mariam had left Jerusalem after going insane. Thus, his cell in the monastery became free. The letter is not clear about what happened after that but it says clearly that the Ethiopians and Armenians argued over this cell and wanted to organize a trial in order to determine what to do with it. The Ethiopians asked for the protection of the French government in the matter. This letter recalls the letters Abd Mariam addressed to the Russian Mission some years earlier in which he depicted himself as the representative of all members of the community and asked for protection against a vague Armenian/ Copt oppression. The French consul did not question the Ethiopian motives. It is reasonable to assume that the words "protection of France" sounded very good to him and covered all other considerations. Immediately, he reported the official demand to his administration. ${ }^{42}$

The above example demonstrates that the conflict involving Armenians/ Copts and Ethiopians over Dayr al-Sultan did not always pit Armenians (or Copts) on one side and Ethiopians on the other. The appeal for European help could be solicited by a part of the community while the other part was looking for support elsewhere. In such documents, the confrontation between Armenians or Copts and Ethiopians, as well as the community's poverty or its isolation, could be topoi that belie the complexity of relationships between Ethiopians and local institutions.

\section{Receipts, Bank Checks and Bills: Signs of Ethiopian Daily Life}

Ethiopian archbishopric archives in Jerusalem preserve documents bearing witness to the involvement of the Ethiopian community in the daily life of Jerusalem. These documents are dated from 1896 to the middle of the twentieth century. They do not concern official relationships with European consulates but rather involve local merchants, local workers, lodgers and civil servants.

41 CADN, Ethiopian letter translated into French (December 6, 1880), Jerusalem, 294PO/ A/134, fol. 19 .

42 CADN, French consul in Jerusalem to French Ministry of Foreign Affairs (December 15, 1880), Jerusalem, 294PO/A/134, fols. 21-25. 


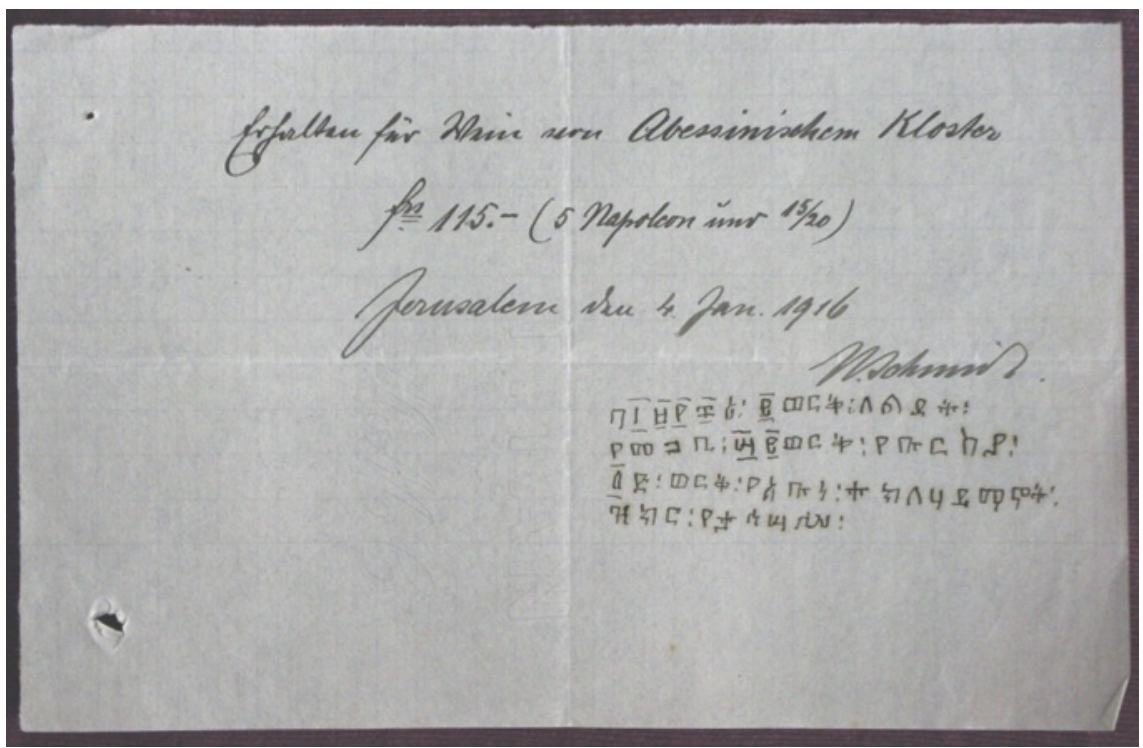

FIGURE 3.4 Receipt for the payment of wine, signed by Nicolai Schmidt, January 4, 1916. EARJ, ARCHIVES SECTION, FOLDER "YÄLEYU LEYU".

They are administrative and financial documents such as payment receipts, tickets, bank checks, bank documents and short letters. ${ }^{43}$ Such documents bear witness to the role of Ethiopians as consumers of goods, users of public services, property owners and employers of Jerusalemite people for works or of middlemen for services. They give also clues to the great flexibility needed for establishing and managing places of worship in Jerusalem. Ethiopians had different interlocutors according to their needs and opportunities. Each interlocutor implied the use of a different language: Arabic, English, French, German, Greek, and/or Armenian. Amharic marginalia were often added to documents in order to provide context or extra information.

Payment receipts were provided by merchants in exchange for goods bought by the community. Among them, receipts for the purchase of wine are particularly interesting. In 1915-16, fifteen receipts are preserved and all of them come from a same shop run by Nicolai Schmidt. All are written in German and signed by him. For example, on January 4, 1916 (fig. 3.4), the community paid for wine that had been used for the celebration (zeker) of the birth of Saint Täklä Haymanot, which takes place annually on Tahasas 24 according to the Ethiopian calendar. The date of the receipt in question corresponds 
to January 3, 1916. The Ethiopian convent also paid for local services such as grinding wheat, as shown by a receipt dated February 24, 1905 (Yäkkatit 17, 1897 according to the Ethiopian calendar) and written in English. The community also rented devices from other communities in Jerusalem. A receipt dated October 17, 1914 (October 4, 1914 according to the Russian calendar) tells us in French that the community rented a water pump from the Russian Orthodox community. Here again, the language of the receipts depended probably on the origin of the worker. For example, an Arabic speaker received money in 1913 for work on the Ethiopian monastery Däbrä Gännät. On April 14, 1915, an English-speaking worker received money for work on Empress Taytu's house (fig. 3.5).

Among these documents, one finds a receipt in Arabic and dated to Muharram 1314 (June 1896). It records payment by Ethiopians living in the old city of a tax for the use of an oven and of a garden (fig. 3.6). ${ }^{44}$ On the document verso, there is a note written in Amharic: "receipt for 6o qirsh (here girsh) for Hanna Karno house" (fig. 3.7). The "History of Dayr al-Sultan" informs us that "five minutes' walk from Dayr al-Sultan monastery," the abbot could stay in a house called "Hanna Karno." For this house, the text says that 60 qirsh was paid per year and one coin of gold for cleaning and lighting. ${ }^{45}$ The name "Hanna Karno" thus referred to the only place where Ethiopians could settle in the old city, the current residence of the Ethiopian archbishop in the old city (Ethiopian Monastery Street). Even if there is little information about the acquisition of this house, it still remains unclear how Ethiopians managed to acquire it. ${ }^{46}$ Italian archives provide some hints, however. Documents refer to a house called "Hanna Carlo," occupied by the Ethiopian abbot Fäqädä Egzi'e in $1903 .{ }^{47}$ This was most probably the same house, "Carlo" being "Karno" in Ethiopian documents. In fact, the Ethiopians received it as a waqf or endowment in 1890 from Johannes Frutiger, a banker in Jerusalem at that time. ${ }^{48}$

Frutiger appeared under other circumstances in sources regarding the Ethiopian community, which raises questions about the role of middlemen in Ethiopian networking in Jerusalem. Ethiopian Empress Taytu entrusted

\footnotetext{
44 Ibid.

45 EARJ, Manuscript section, MS JE692E, 289.

46 Pedersen, History of the Ethiopian Community, 47-48.

47 ASD, Ministero dell'Africa Italiana, Italian consul in Jerusalem to Italian Ministry of Foreign Affairs (May 4, 1903), Jerusalem, posizione 42-3.

48 ASD, Ministero dell'Africa Italiana, Italian consul in Jerusalem to Italian Ministry of Foreign Affairs (July 3, 1903), Jerusalem, posizione 42-3.
} 


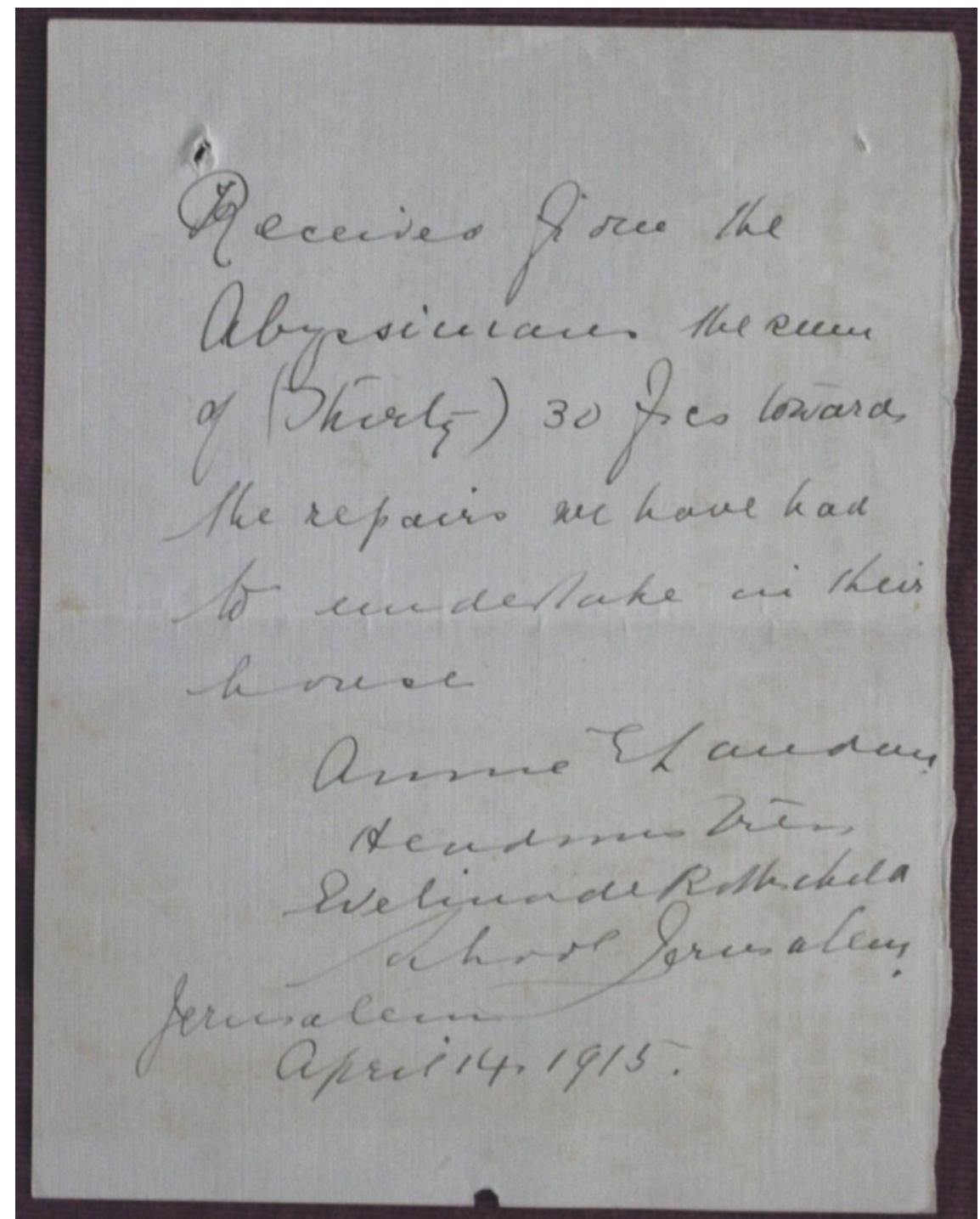

FIGURE 3.5 Receipt for payment for work done on Empress Taytu's house, April 14, 1915. EARJ, ARCHIVES SECTION, FOLDER "YÄLEYU LEYU".

an Ethiopian prince, ras Makonnen, with money to buy a house for her in Jerusalem. But Makonnen could not buy himself a house without being a Jerusalem resident. Thus, the Italian consulate was contacted and finally it was given the responsibility of purchasing the house with the money given by Makonnen. A house was found and the owners, Mathilde and Giulia Ungar, signed a deed of sale with Italian consul Solanelli, who acted on behalf of 


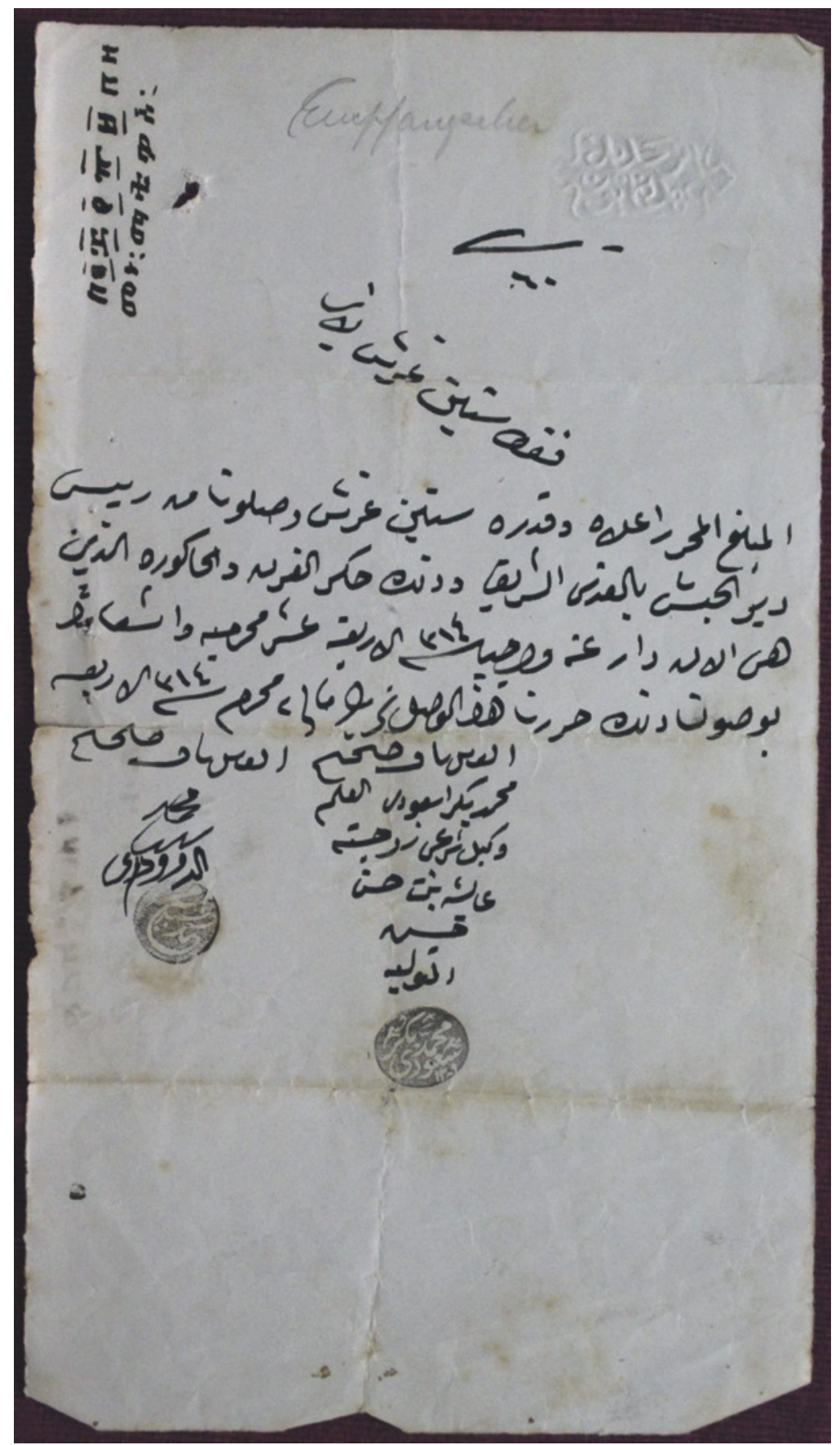

FIGURE 3.6 Receipt for the payment of tax (recto), Muharram 1314 (June 1896). EARJ, ARCHIVES SECTION, FOLDER "YÄLEYU LEYU". 


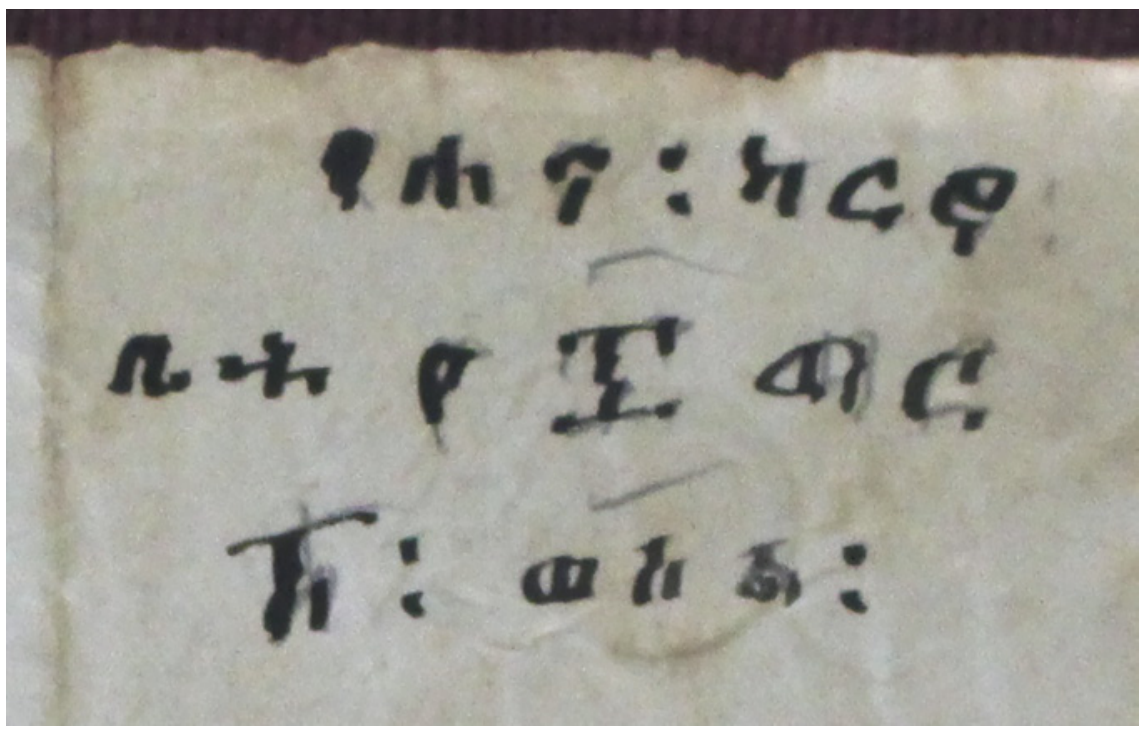

FIGURE 3.7 Receipt for the payment of tax (verso), Muharram 1314 (June 1896). EARJ, ARCHIVES SECTION, FOLDER "YÄLEYU LEYU".

Makonnen on January $7,189 .^{49}$ During the procedure, Frutiger acted on behalf of the former owners of the house, serving as a guarantor and intermediary with the Italian consulate. ${ }^{50}$

The Ethiopian archives hold two small documents highlighting the role of another middleman. ${ }^{51}$ A short document written in August 1913 in French testifies the role of Pascal Seraphin in collecting information about houses for sale or rent in Palestine on behalf of the Ethiopian community (fig. 3.8). A similar document is preserved in the Italian archives. In a short letter to the Italian consul dated to 1903, Seraphin gave precise information concerning a house next to Empress Taytu's residence. ${ }^{52}$ An architect in Jerusalem, Seraphin was

49 ASD, Ministero dell'Africa Italiana, document in Italian and attached to Italian consul's letter to Italian Ministry of Foreign Affairs (January 7,1890 ), Jerusalem, posizione 42-1.

50 ASD, Ministero dell'Africa Italiana, Copy of declaration of Johannes Frutiger as guarantor (May 5, 1890), in French, attached to Italian consul's letter to Italian Ministry of Foreign Affairs (May 6, 189o), Jerusalem, posizione 42-1; ASD, Ministero dell'Africa Italiana, Receipt signed by Johannes Frutiger (May, 1890), Jerusalem, posizione 42-1.

$5^{1} \quad$ EARJ, Archives section, folder "Yäleyu leyu."

$5^{2}$ ASD, Ministero dell'Africa Italiana, Pascal Seraphin to Italian consul in Jerusalem (December 15, 1903), Jerusalem, posizione 42-3. 


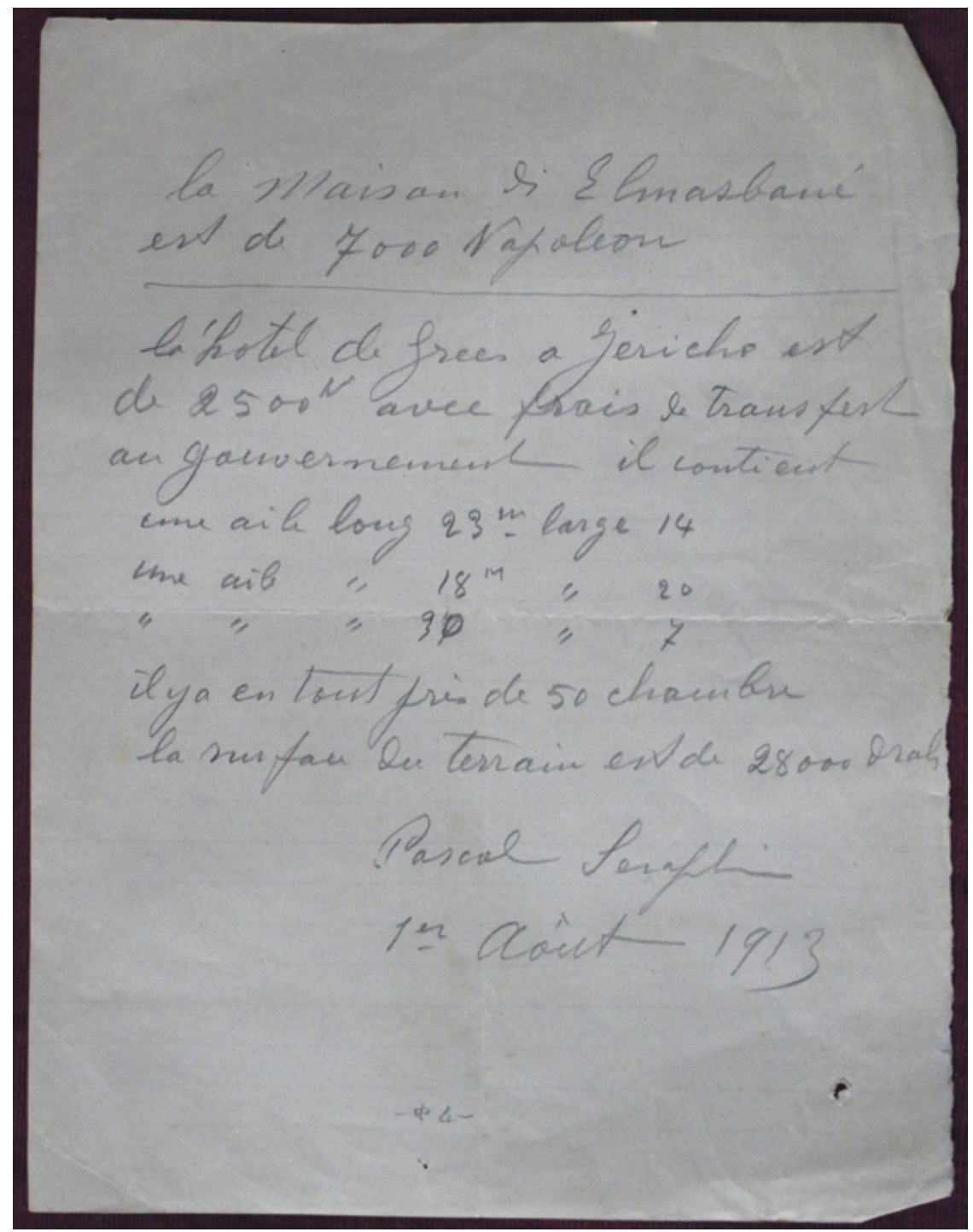

FIG URE 3.8 Short note signed by Pascal Seraphin, August 1, 1913.

EARJ, ARCHIVES SECTION, FOLDER "YÄLEYU LEYU".

hired in 1902 by the Italian consulate in order to carry out works on Empress Taytu's house. Known as "Ungar House" after the name of its previous owners, the house needed major construction work. At first, the Ethiopians contacted the French consulate in Jerusalem in 19oo. The French consul proposed that an Augustine monk living in Jerusalem, Father Etienne, perform the 


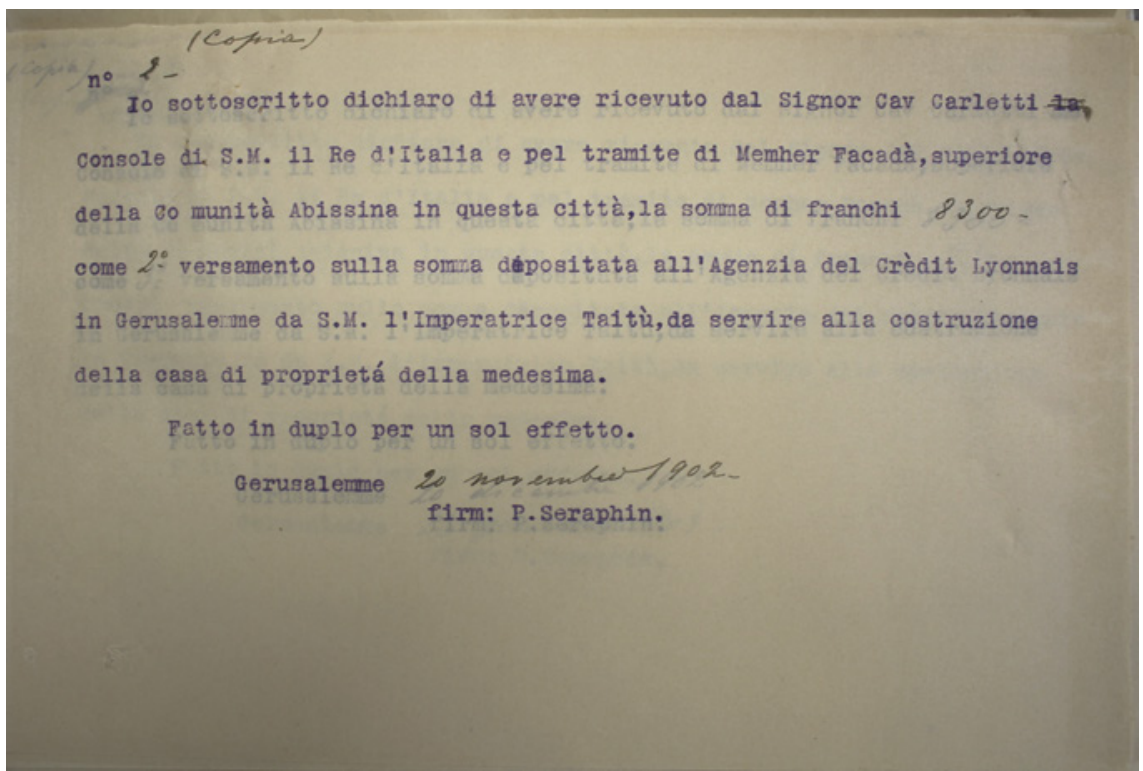

FIGURE 3.9 Receipt for payment for work done on Empress Taytu's house, signed by Pascal Seraphin, November 20, 1902.

ASD, MiNisTERO DELL'AFRICA ITALIANA, POSIZIONE 42-3.

work, ${ }^{53}$ but the Ethiopians changed their plans and entrusted the job to the Italian consulate, which ended up supervising the reconstruction in $1902 .{ }^{54}$ The Italian consulate chose Seraphin at that point. Receipts signed by him for the payment of his labor are preserved in the Italian archives (fig. 3.9) and bear witness to his activities. ${ }^{55}$ Apparently, he continued to provide services at least until 1913. After his death, his family in Jerusalem remained somewhat dependent on the Ethiopian community. His wife sent a letter, unfortunately undated, to the Ethiopian abbot (fig. 3.10), ${ }^{56}$ requesting help from the community in exchange for the "numerous services done by [her] husband." The Ethiopian abbot at the time was Mahtsantä Sellase, who was in

53 CADN, French consul in Jerusalem to French Ministry of Foreign Affairs (October 13, 1900), 294PO/A/134, fol. 211-12.

54 CADN, French consul in Jerusalem to French Ministry of Foreign Affairs (September 28, 1903), 294PO/A/134, fols. 279-80.

55 ASD, Ministero dell'Africa Italiana, Receipts signed by Pascal Seraphin (November 20, 1902), posizione $42-3$.

$5^{6}$ EARJ, Archives section, folder “Yäleyu leyu." 


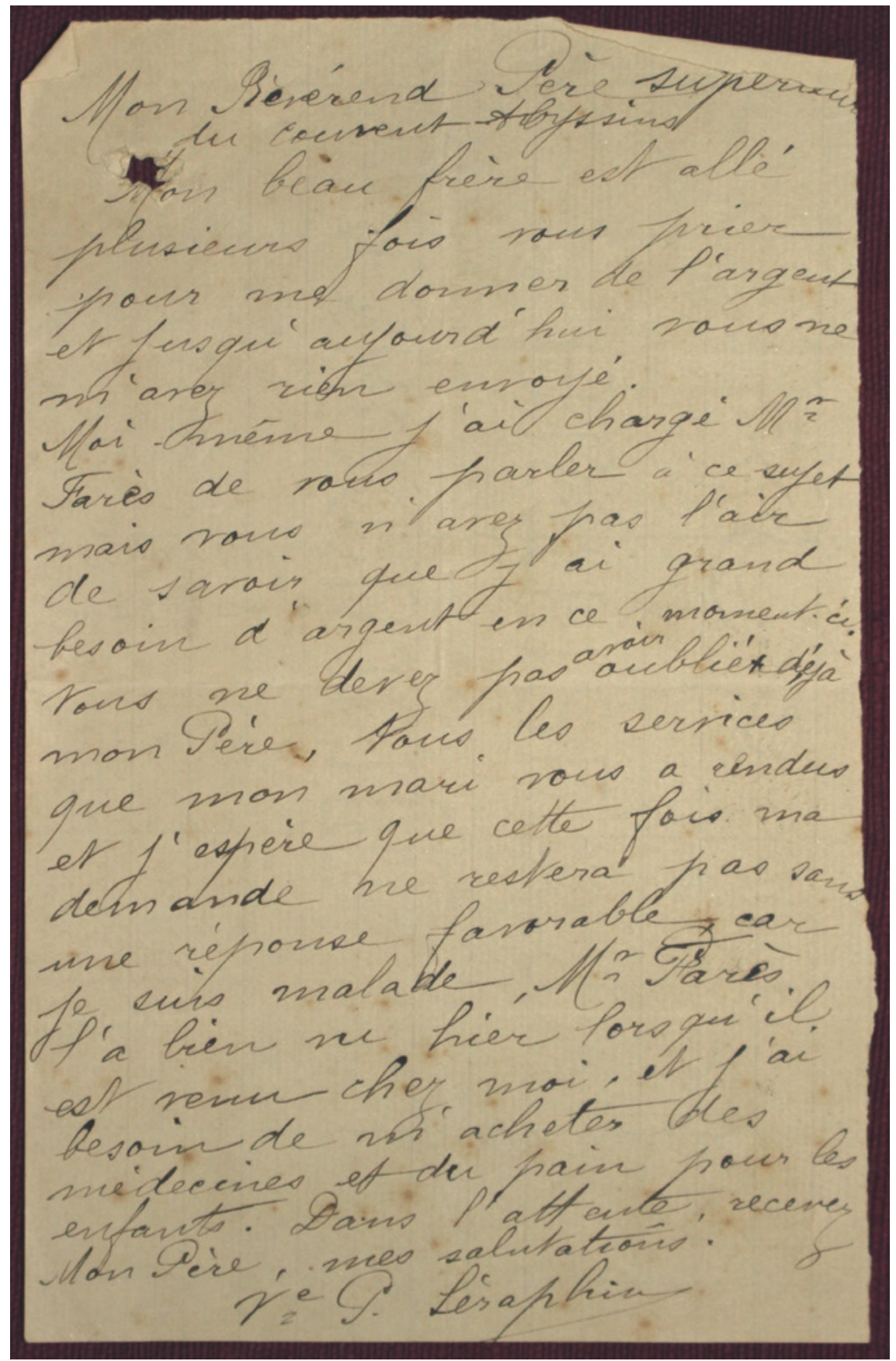

FIGURE 3.10 Short letter from Seraphin's wife, n.d.

EARJ, ARCHIVES SECTION, FOLDER "YÄLEYU LEYU". 
charge of the community from 1906 to 1923 and the only abbot to have been aware of Seraphin's activities after 1913.

\section{Conclusion}

Information about the daily life of the Ethiopian Orthodox community from 1840 to 1940 is not easy to find: no substantial efforts have been made so far to characterize or understand it. However, a new approach and new archival material can reveal perspectives and can alert scholars to some methodological traps. This study is still very much in progress. The analysis of the documents discussed in this chapter is under way and new archival material from other institutions in Jerusalem will be added to them shortly. Nonetheless, we already have new insights into the daily lives of Ethiopians in Jerusalem. This chapter shows that European and Ethiopian sources themselves have so far prevented scholars from gaining a deep understanding of the Ethiopian conditions in Jerusalem during the period under scrutiny. Provided they are carefully analyzed and connections are established among them, these sources can provide valuable information concerning the social networks of members of the community. Members of the Ethiopian community did not passively wait for other communities to decide on their behalf whether to help them. On the contrary, they established contacts with all segments of Jerusalem social life and, therefore, played an active role in the daily life of the city. 